\title{
STUDIES ON THE BEST TIME FOR CULTIVATION AND PRODUCTION OF VEGETABLE SOYBEAN UNDER EGYPTIAN CONDITION.
}

\author{
Ewais A. Nabila
}

Vegetable Research Department, Horticulture Research Institute, Agriculture Research Center, Giza, Egypt.

Key Words: vegetable soybean, sowing dates, Egyptian conditions.

\section{ABSTRACT}

Two field experiments were carried out in the experimental farm of Barrage Horticulture Research station of the Agricultural Research Center, Qalubia Governorate, Egypt. during two summer seasons of 2017 and 2018 to study the effect of sowing date (1st April, 1st May and 1st June) on two cultivars of vegetable soybean (K173 - Royston Petrie).The experimental design was a split plot design the main plots were the three sowing dates and the sub plots were the two vegetable soybean cultivars. The results indicated that the third date (1st June) gave the highest values in plant length in the both seasons, number of leaves/ plant and number of branches/ plant in the first season. And the first sowing date (1st April) significantly increased the 100 green seeds weight and net ratio of green pods in both seasons too. But the second sowing date (1st May)) gave a significant effect on green pod number of green pod / plant, total yield of green pod (ton/ Fed) and gave significantly increased in the total sugars content in green seeds in the both seasons. The K173 cv. gave the highest number of green pod/ plant, total yield of green pod (ton/ Fed), \% Potassium and the total sugars content in green seeds in the first and the second seasons, \% phosphorus contents in green seeds in the first season. However Royston Petrie cv. recorded significant effect in number of nods to first pod, green pod weight, net ratio of green pods, \% nitrogen and \% protein in green seeds in the first and the second seasons. K173cv. which sowing in the third date (1st June) gave the highest plant length, number of leaves/ plant, number of branches/ plant and stem length in both seasons. Also K173cv.with second sowing date (1st May) gave the highest number of green pod/ plant, total yield of green pod (ton/ Fed) in the first and the second season. However The Royston Petrie $\mathrm{cv}$. gave highest number of nods to first pod with the third sowing date (1st June) in the first season. Sowing the Royston Petrie cv. in the first sowing date (1st April) significantly increased green pod weight and net ratio of green pods in both seasons

\section{INTRODUCTION}

Vegetable soybean or edamame is a specialty soybean (Glycine max Merrill). Edamame is known by many names (Shurtleff, Aoyagi, unpublished, beer bean, edible soybean, fresh green soybean, garden soybean, green soybean, green-mature soybean, green vegetable soybean, 
immature soybean, large-seeded soybean, vegetable-type soybean) but the most common is vegetable soybean ( Konovsky et al., 1994). Also is called (mao dou) in China and (poot kong) in Korea (Saldivar et al., 2011). Edamame can be transplanted or direct-seeded. It harvested as a fresh vegetable before fully filled green pods turn yellow (Zhang et al., 2007). The seeds of vegetable soybeans are larger, sweeter and tender than that of grain soybean. Because of its excellent nutrition and slightly sweet taste, mild flavor and nutty texture, with less objectionable beany taste, it is preferred over conventional grain soybeans as a fresh green bean (Lee and Hwang, 1998). Vegetable soybean is a very important crop for Vegetabletype soybean, rich in protein, fat (without cholesterol), minerals, and vitamins, is harvested when the pod is still green and full. The green seeds shelled from the immature pods are quick-to-cook, free from off-flavour, and more importantly, their appearance as well as cooking method being similar to that of other immature beans viz. green pea, chick pea, French bean (Kumar et al., 2011).

Vegetable soybean originates from China and cultivated for more than 5,000 years, spreading from China to neighboring countries such as Korea, Japan, India, Indonesia, Malaysia, Nepal, the Philippines, Thailand and Vietnam. The main soybean producing countries are the United States, Brazil, Argentina, China, India, Paraguay, Canada and Indonesia, which together produce $80 \%$ of the world's soybean (Slaton $\boldsymbol{e t}$ al., 2008 and Shanmunga 2009). The crop is well known and widely used in Asia and America, but less known in Africa (Chadha and Oluoch, 2004).There is high research interest for edamame in Asia and America (Basavaraja et al., 2005) but in Africa, research on edamame is very scarce. Currently, soybean is one of the most important crops in the world but it is a new non-traditional culture for our country, which has great potential and interest for introducing it in Egypt. Sowing date is a good approach to enhance both crop yield and economic benefit. Effects of planting date on soybean yield and other traits varied at locations (Hoeft et al., 2000; Naeve et al., 2004). Edamame is easy and reliable to grow, but wait until weather warms before planting; cold and/or wet conditions prevent good germination. In spring, once weather is warm and night's stay securely above $\left(13^{\circ} \mathrm{C}\right)$, sow in well-worked, fertile soil in full sun. The yielding ability of vegetable soybean may be affected by its sowing time due to adverse weather conditions and the number of pods, the green soybean yield decreased with delay in the sowing time (Nishioka and Okumura, 2008; Zhang et al., 2008). Sowing date is the variable with the largest effect on crop yield (Calvino et al., 2003a, b). Fine-tune management of soybean by sowing date is a good approach to enhance both crop yield and economic benefit. Effects of planting date on soybean yield and other traits varied at locations (Hoeft et al., 2000; Naeve et al., 2004). Environmental conditions associated with late sowing affect crop features 
related to the capture of radiation and portioning of crop resources. These include less vegetative growth (Board et al., 1992), shorter stems (Boquet, 1990), lower reproductive nodes (Board et al., 1999), and shortening of the reproductive phases (Kantolic and Slafer, 2001). The yielding ability of green soybean may be affected by its sowing time due to adverse weather conditions and the number of pods set; the green soybean yield decreased with delay in the sowing time (Nishioka and Okumura, 2008; Zhang et al., 2008). Large pods containing many grains are considered to be of good quality. While variation in soybean planting date is expected to impact the pattern of soybean growth and development, very few reports have been examined in vegetable soybean.

The objective of this study was to examine the effect of different sowing dates on vegetative growth, yield, and yield components of two genotypes of soybean (Glycine max Merrill) under Egyptian conditions. The ultimate goal is produce vegetable soybean in the summer season to fill the deficit resulting from the absence of leguminous vegetables in the Egyptian markets.

\section{MATERIAL AND METHODS}

Two field experiments were carried out during the summer season of 2017 and 2018 at Barrage Horticulture Research station of the Agricultural Research Center (A. R. C.), Qalubia Governorate, Egypt, to study the effect of sowing dates on plant growth characters, yield and its components, and the chemical composition of leaves and fresh seeds of two vegetable soybean cultivars (Edamame). The soil was clay loam with $\mathrm{pH}$ 8.28. The meteorological data during 2017 and 2018 prevailing at Qalubia governorate region were given in Table (1).

Table (1). Maximum air temperature of Qalubia governorate region during the summer seasons of 2016 and 2017.

\begin{tabular}{|c|c|c|c|c|c|}
\hline \multirow{2}{*}{ Months } & & \multirow{2}{*}{$\frac{\text { Max. }}{2017}$} & \multirow{2}{*}{$\begin{array}{l}\text { Air temperature } C^{0} \\
2018\end{array}$} & \multicolumn{2}{|c|}{ Min. Air temperature $C^{o}$} \\
\hline & & & & 2017 & 2018 \\
\hline April & & 37.9 & 39.1 & 13.4 & 14.6 \\
\hline May & & 45.1 & 45.8 & 16.9 & 17.1 \\
\hline June & & 39.7 & 43.7 & 19.7 & 20.2 \\
\hline July & & 41.9 & 41.4 & 17.6 & 15.9 \\
\hline August & & 43.5 & 39.5 & 13.9 & 14.2 \\
\hline & September & 38.9 & 39.7 & 15.7 & 14.9 \\
\hline Mean & & 41.2 & 41.5 & 16.1 & 16.3 \\
\hline
\end{tabular}

\section{The treatments were as following}

A. Sowing dates: 1st April, 1st May and 1st June

B. Two cultivars were tested in this experiment which were:

K173: Early maturing, full of antioxidants, sweeter than other varieties and great for eating fresh or freezing. 
Royston Petrie: A variety that's early to mature and regularly produces pods with two to three beans.

The experimental design:-

These treatments were arranged in split plot design with three replicates in both seasons .Sowing dates were assigned at the main plots, while sub plots were devoted two vegetable soybean cultivars. Each experimental plot area was $9 \mathrm{~m} 2$ where including of five ridges $(3 \mathrm{~m}$ length and $0.60 \mathrm{~m}$ width). Seeds of both cvs were sowing at $10 \mathrm{~cm}$ apart on one side of ridge .

All agricultural practices for growing soybean were followed as recommended by the Ministry of agriculture for soybean as field crop because there are no present recommendations for it as vegetable crop under Egypt condition.

\section{Data recorded:-}

\section{Vegetative growth characters}

Five plants from each plot were randomly taken at seed sitting stage (65 days after sowing) in the two seasons and the following data were recorded.

1.1. Plant length (the length of main stem $(\mathrm{cm})$.

1.2. Stem diameter $(\mathrm{cm})$.

.1.3. Number of branches per plant

1.4. Number of leaves per plant

1.5. Number of nods to first pod

1.6. Total leaf chlorophyll (at flowering stage) in the fourth upper leaf (three readings per leaf at different places) it was measured by using Minolta chlorophyll meter (SPAD-501) as SPAD units (Yadava 1986). -

\section{Green pods yield and its components}

A random sample of ten pods from each plot, were taken on marketable stage for green pods to determine.

2.1. Pods number of / plant

2.2. Average Pod length $(\mathrm{cm})$

2.3. Average Pod diameter $(\mathrm{cm})$

2.4. Average Pod weight ( $\mathrm{g})$

2.5. Pods weight/plant $(\mathrm{g})$

2.6. Seeds weight/plant (g).

2.7. Net ratio of green pods.

2.8. Weight of 100 green seeds $(\mathrm{g})$.

2.9. Total green pods yield (ton/fed).

Green pods of each plot were continuously harvested at suitable maturity stage, counted and weighted then Green pod (yield/ feddan) it was calculated as sum of all harvests per plot, then converted to (yield/ feddan). 


\section{3- Green seed chemical analysis}

The green seeds (were taken at 90days after sowing) dried at $70{ }^{\circ} \mathrm{C}$ in forced air oven for 72 hours, and then finely ground to determine the following chemical analysis.

-3.1.Total nitrogen, potassium and phosphorus on dry weight of vegetable soy bean green seeds so were determined on the basis of dry weight according to (Pregl 1945), (Brown and Lilleland 1946) and (Jackson 1967) respectively.

Total protein was calculated as multiplying nitrogen by 6.25

3.2. Total sugars were determined colorimetric according to the method described by (Dubois et al. 1975).

\section{Statistical analysis}

Data obtained were subjected to the proper analysis of variance (split plot design) as described by Snedecor and Cochran (1980) using 8 statistics. Averages between treatments were differentiated by using (L.S.D) at $5 \%$ level of probability.

\section{RESULTS AND DISCUSSION}

\section{1-Vegetative growth characters}

Data presented in Table (2) illustrated that delay in sowing date $\left(1^{\text {st }}\right.$ June) significantly excelled on some parameters of plant growth expressed as plant height, number of leaves and branches per plant compared to the others planting date. This could be mainly due to suitable temperature prevailing during growing period (Table 1). (Cakmakci \& Oral 2001) reported that thermo period refers to daily temperature change; however, plants produce maximum growth when exposed to a day temperature that is about 10 to $15 \mathrm{C}^{\circ}$ higher than the night temperature. This allows the plant to photosynthesize (build up) and respire (break down) during an optimum daytime temperature, and to curtail the rate of respiration during night. On the other side different sowing dates did not significant differences in the obtained results of stem diameter, number of nods to first pod and leaf chlorophyll content.

Concerning the behavior of cultivars to sowing date, it is clear in Table (2) that the obtained growth parameters of plants differed among cultivars however, cv. K137 gave significantly longest plants and has much number of leaves per plant beside containing highest amount of chlorophyll in their leave than $\mathrm{cv}$. Royeston petrie. While the other growth parameters i.e., number of branches per plant, stem diameter and number of nods did not significantly differences between cultivars. Many investigators supported our results such as (Faris \& Abd ELHakeem, 1992), and (Helal et al., 2006) who reported that variation among cultivars could be attributed to the genetic factors.

Regarding the interaction between investigated cultivars and sowing date for vegetative growth recorded data in Table ( 2 ) showed 
that the highest plant length number of leaves/ plant and number of branches/ plant were detected from K173cv. which sowing in the third date $\left(1^{\text {st }}\right.$ June). Also the number of nods to first pod gave the highest value from K173 cv. in the second sowing date $\left(1^{\text {st }}\right.$ May) but in the first season. While the chlorophyll content significantly increased as a result of sowing the Royston Petrie cv. in the first sowing date ( $1^{\text {st }}$ April) in the first and the second seasons.

\section{Green pods yield and its components}

The results of green pod yield and its component are presented in Table (3). In general the first date $\left(1^{\text {st }}\right.$ April) obtained the highest values on weight of 100 green seeds and net ratio of green pods in both seasons. Meanwhile the second date ( $1^{\text {st }}$ May) produced much number of pod per plant, pods weight per plant and total yield (ton/Fed). On the other hand late sowing date $\left(1^{\text {st }}\right.$ June) gave the lowest values of all the above parameters. That means, the sowing date in first may is the best sowing date, and sowing date in June must be avoided due to reduction in yield and yield components. It clear that the difference in temperature (Table 1) and photoperiod length during different growth stages strongly influences the shape of soybean plant by bringing about a change in flowering and maturation time and dry matter production. Length of photoperiod strongly influences the morphology of soybean plant by causing change in the time of flowering, maturity and dry matter production. This leaned heavily on yield and yield components of vegetable soybean. These results agreed with (Woong and Yamakawa 2006) who reported that the number of pods and seed per plant decreased as planting date delayed. on the other hand (Bastidas et al.,2008) found that yield was significantly affected by planting date. This result also, was in line with (Zhang, et al., 2010), and (Moosavi et al., 2011) who illustrated the importance of early sowing for maximizing the yield potential of soybean. From another point of view high temperature causes an increase in respiration, sometimes above the rate of photosynthesis. This means that the products of photosynthesis are being used more rapidly than they are being produced. For growth to occur, photosynthesis must be greater than respiration as happened in the third sowing date ( $1{ }^{\text {st }}$ June) causing a reduction in obtained

Regarding to the effect of cultivars data illustrated in Table (3) show clearly that the $\mathrm{K} 173 \mathrm{cv}$. had a significant increase plant pods, the weight of plant pods, the weight of plant seeds, and total green pods yield (ton/ Fed) in the first and the second seasons. On the other side the green pod weight and net ratio of green pods gave significant increase with Royston Petrie cv. in the second seasons. This is contrary to the results of (Zhang, et al., 2010) who found yield significantly increased among vegetable soybean varieties which because the genetic predisposition. 
Table (2): Effect of the sowing dates and cultivars on vegetative growth and leaf chlorophyll content of vegetable soybean plants during the two seasons of 2017 and 2018.

\begin{tabular}{|c|c|c|c|c|c|c|c|c|c|c|c|c|c|}
\hline \multirow{2}{*}{\multicolumn{2}{|c|}{ Treatments }} & \multicolumn{2}{|c|}{ Plant length (cm) } & \multicolumn{2}{|c|}{ No., of Leaves } & \multicolumn{2}{|c|}{ No., of Branches } & \multicolumn{2}{|c|}{$\begin{array}{l}\text { Stem diameter } \\
(\mathbf{c m})\end{array}$} & \multicolumn{2}{|c|}{$\begin{array}{l}\text { No., of nods to } \\
\text { first pod }\end{array}$} & \multicolumn{2}{|c|}{$\begin{array}{l}\text { Chlorophyll } \\
\text { (SPAD) }\end{array}$} \\
\hline & & $\begin{array}{c}1^{\text {st }} \\
\text { season }\end{array}$ & $\begin{array}{c}2^{\text {nd }} \\
\text { season }\end{array}$ & $\begin{array}{c}1^{\text {st }} \\
\text { season }\end{array}$ & $\begin{array}{c}2^{\text {nd }} \\
\text { season }\end{array}$ & $\begin{array}{c}1^{\text {st }} \\
\text { season }\end{array}$ & $\begin{array}{c}2^{\text {nd }} \\
\text { season }\end{array}$ & $\begin{array}{c}1^{\text {st }} \\
\text { season }\end{array}$ & $\begin{array}{c}2^{\text {nd }} \\
\text { season }\end{array}$ & $\begin{array}{c}1^{\text {st }} \\
\text { season }\end{array}$ & $\begin{array}{c}2^{\text {nd }} \\
\text { season }\end{array}$ & $\begin{array}{c}1^{\text {st }} \\
\text { season }\end{array}$ & $\begin{array}{c}2^{\text {nd }} \\
\text { season }\end{array}$ \\
\hline \multicolumn{14}{|c|}{ Sowing date } \\
\hline \multicolumn{2}{|l|}{$1^{\text {st }}$ April } & 55.5 & 63.17 & 101.67 & 90.83 & 32.83 & 38.00 & 1.00 & 1.00 & 4.33 & 5.00 & 44.45 & 45.37 \\
\hline \multicolumn{2}{|l|}{$1^{\text {st }}$ May } & 48.0 & 55.5 & 92.00 & 90.00 & 30.50 & 36.33 & 0.98 & 0.98 & 3.67 & 4.67 & 42.97 & 42.20 \\
\hline \multicolumn{2}{|l|}{$1^{\text {st }}$ June } & 60.35 & 65.22 & 102.33 & 103.67 & 35.90 & 37.67 & 0.73 & 0.72 & 4.11 & 4.67 & 43.33 & 43.00 \\
\hline \multicolumn{2}{|l|}{ L.S.D at $5 \%$} & 4.48 & 5.60 & 5.02 & N.S & 2.59 & N.S & N.S & N.S & N.S & N.S & N.S & N.S \\
\hline \multicolumn{14}{|c|}{ Soybean } \\
\hline \multicolumn{2}{|c|}{$\mathbf{K}$} & 53.33 & 66.33 & 103.83 & 90.67 & 32.50 & $\mathbf{3 8 . 5 0}$ & 0.91 & 0.90 & 3.50 & 3.83 & 46.48 & 44.02 \\
\hline \multicolumn{2}{|c|}{$\mathbf{R}$} & 50.17 & 52.33 & 89.83 & 90.17 & 31.83 & 35.83 & 0.90 & 0.90 & 4.50 & 4.83 & 40.93 & 43.55 \\
\hline \multicolumn{2}{|l|}{ L.S.D at $5 \%$} & N.S & 2.96 & 4.14 & N.S & N.S & N.S & N.S & N.S & 0.65 & 0.53 & N.S & N.S \\
\hline \multicolumn{14}{|c|}{ Interaction } \\
\hline \multirow[b]{2}{*}{ First April } & $\mathbf{K}$ & 56.00 & 58.33 & 102.67 & 92.33 & 39.67 & 40.67 & 1.00 & 1.00 & 4.00 & 4.00 & 46.17 & 45.63 \\
\hline & $\mathbf{R}$ & 55.00 & 56.00 & 81.33 & 87.67 & 33.00 & 34.00 & 1.00 & 1.00 & 4.33 & 4.67 & 48.73 & 46.77 \\
\hline \multirow[t]{2}{*}{ First May } & $\mathbf{K}$ & 58.67 & 59.33 & 98.00 & 99.00 & 42.00 & 41.33 & 0.97 & 0.97 & 4.00 & 4.00 & 45.70 & 46.40 \\
\hline & $\mathbf{R}$ & 49.33 & 56.67 & 94.33 & 92.67 & 33.00 & 34.67 & 1.00 & 1.00 & 4.67 & 4.67 & 44.23 & 44.33 \\
\hline \multirow[t]{2}{*}{ First June } & $\mathbf{K}$ & 66.97 & 67.33 & 103.11 & 102.67 & 43.33 & 42.67 & 0.77 & 0.73 & 3.67 & 3.93 & 45.67 & 44.84 \\
\hline & $\mathbf{R}$ & 64.33 & 63.67 & 98.95 & 99.33 & 38.87 & 39.33 & 0.70 & 0.70 & 4.83 & 4.33 & 44.33 & 45.22 \\
\hline \multicolumn{2}{|l|}{ L.S.D at $5 \%$} & 0.25 & 0.19 & 0.12 & 0.11 & 0.25 & 0.02 & N.S & N.S & 0.13 & N.S & N.S & N.S \\
\hline
\end{tabular}

K = K173 cv. $R=$ Royston Petrie 
Table (3): Effect of the sowing dates and cultivars on Green pods yield and its components of vegetable soybean plants during the two seasons of 2017 and 2018 .

\begin{tabular}{|c|c|c|c|c|c|c|c|c|c|c|c|c|c|c|c|c|c|c|c|}
\hline \multirow{2}{*}{\multicolumn{2}{|c|}{ Treatments }} & \multicolumn{2}{|c|}{$\begin{array}{c}\text { No., of } \\
\text { pods/plant }\end{array}$} & \multicolumn{2}{|c|}{$\begin{array}{c}\text { Pod } \\
\text { length }(\mathrm{cm})\end{array}$} & \multicolumn{2}{|c|}{$\begin{array}{c}\text { Pod } \\
\text { diameter } \\
(\mathbf{c m})\end{array}$} & \multicolumn{2}{|c|}{$\begin{array}{l}\text { Average } \\
\text { green pod } \\
\text { weight (g) }\end{array}$} & \multicolumn{2}{|c|}{$\begin{array}{c}\text { Average } \\
100 \text { green seeds } \\
\text { weight } \\
(\mathrm{g})\end{array}$} & \multicolumn{2}{|c|}{$\begin{array}{l}\text { Total yield } \\
\text { (ton/ Fed) }\end{array}$} & \multicolumn{2}{|c|}{$\begin{array}{c}\text { green pods } \\
\text { weight/plant } \\
\text { (g) }\end{array}$} & \multicolumn{2}{|c|}{$\begin{array}{c}\text { green seeds } \\
\text { weight/plant } \\
\text { ( g) }\end{array}$} & \multicolumn{2}{|c|}{$\begin{array}{c}\text { Net ratio of } \\
\text { green pods } \\
(\%)\end{array}$} \\
\hline & & $\begin{array}{c}1^{\text {st }} \\
\text { season } \\
\end{array}$ & $\begin{array}{c}2^{\text {nd }} \\
\text { season }\end{array}$ & \begin{tabular}{|c|}
$1^{\text {st }}$ \\
season \\
\end{tabular} & \multirow{2}{*}{$\begin{array}{c}2^{\text {nd }} \\
\text { season } \\
\end{array}$} & $\begin{array}{c}1^{\text {st }} \\
\text { season }\end{array}$ & \begin{tabular}{|c|}
$2^{\text {nd }}$ \\
season
\end{tabular} & $\begin{array}{c}1^{\text {st }} \\
\text { season }\end{array}$ & $\begin{array}{c}2^{\text {nd }} \\
\text { season }\end{array}$ & $\begin{array}{c}1^{\text {st }} \\
\text { season }\end{array}$ & $\begin{array}{c}2^{\text {nd }} \\
\text { season }\end{array}$ & $\begin{array}{c}1^{\text {st }} \\
\text { season }\end{array}$ & $\begin{array}{c}2^{\text {nd }} \\
\text { season }\end{array}$ & $\begin{array}{c}1^{\text {st }} \\
\text { season }\end{array}$ & $\begin{array}{c}2^{\text {nd }} \\
\text { season }\end{array}$ & \multicolumn{2}{|c|}{$\begin{array}{cc}1^{\text {st }} \quad 2^{\text {nd }} \\
\text { season season }\end{array}$} & \begin{tabular}{|c|}
$1^{\text {st }}$ \\
season
\end{tabular} & $\begin{array}{c}2^{\text {nd }} \\
\text { season }\end{array}$ \\
\hline & & & & & & \multicolumn{14}{|c|}{ Sowing date } \\
\hline First April & & 85.50 & 85.83 & 5.03 & 5.05 & 1.00 & 1.00 & 0.99 & 0.92 & 18.65 & 17.95 & 5.77 & 5.79 & 84.63 & 78.37 & 44.48 & 42.42 & 52.58 & 54.15 \\
\hline First May & & 99.00 & 91.67 & 5.25 & 4.97 & 0.98 & 0.98 & 0.98 & 0.92 & 16.76 & 16.66 & 6.39 & 6.36 & 96.40 & 84.03 & 44.85 & 41.26 & 46.61 & 48.75 \\
\hline First June & & 67.33 & 66.83 & 4.30 & 4.22 & 0.73 & 0.72 & 0.84 & 0.82 & 15.88 & 15.57 & 4.70 & 4.67 & 56.83 & 55.03 & 18.45 & 17.72 & 32.29 & 32.03 \\
\hline L.S.D at $5 \%$ & & 3.02 & 1.36 & N.S & N.S & N.S & N.S & N.S & N.S & 0.75 & 0.63 & 0.30 & 0.27 & 3.43 & N.S & N.S & 1.43 & 1.67 & 2.08 \\
\hline \multicolumn{20}{|c|}{ Soybean Cultivars } \\
\hline \multicolumn{2}{|l|}{$\mathbf{K}$} & 89.95 & 85.98 & 4.74 & 4.69 & 0.91 & 0.90 & 0.92 & 0.85 & 17.32 & 15.89 & 5.66 & 5.35 & 83.84 & 72.14 & $\mathbf{3 7 . 1 0}$ & 31.85 & 43.28 & 43.34 \\
\hline $\mathbf{R}$ & & 78.48 & 73.33 & 4.98 & 4.80 & 0.90 & 0.90 & 0.95 & 0.93 & 16.88 & 17.16 & 4.64 & 4.47 & 74.74 & 72.61 & 34.75 & 35.75 & 44.37 & 46.61 \\
\hline L.S.D at $5 \%$ & & 1.85 & 2.11 & N.S & N.S & N.S & N.S & N.S & 0.03 & N.S & 0.72 & 0.24 & 0.12 & 6.52 & N.S & N.S & N.S & N.S & 0.44 \\
\hline & & & & & & Intera & tion & & & & & & & & & & & & \\
\hline First April & $\mathbf{K}$ & 93.33 & 94.33 & 5.00 & 4.87 & 1.00 & 1.00 & 0.95 & 0.83 & 18.42 & 18.55 & 5.30 & 6.79 & 88.70 & 78.62 & 46.44 & 41.13 & 52.36 & $\mathbf{5 2 . 3 0}$ \\
\hline & $\mathbf{R}$ & 77.67 & $\mathbf{7 7 . 3 3}$ & 5.07 & 5.25 & 1.00 & 1.00 & 1.30 & 1.10 & 19.29 & 19.15 & 3.80 & 3.39 & 80.55 & 78.12 & 42.51 & 43.72 & 54.87 & 55.99 \\
\hline First May & $\mathbf{K}$ & 105.3 & 91.00 & 4.83 & 4.90 & 0.97 & 0.97 & 0.95 & 0.56 & 16.64 & 16.20 & 5.82 & 6.42 & 99.63 & 77.80 & 43.46 & 34.10 & 43.59 & 43.84 \\
\hline & $\mathbf{R}$ & 92.67 & 92.33 & 5.67 & 5.03 & 1.00 & 1.00 & 1.07 & 0.98 & 17.38 & 17.27 & 4.56 & 4.50 & 93.18 & 90.26 & 46.24 & 48.41 & 49.62 & 53.67 \\
\hline First June & $\mathbf{K}$ & 72.33 & $\mathbf{7 0 . 3 3}$ & 4.40 & 4.30 & 0.77 & 0.73 & 0.87 & 0.85 & 15.30 & 15.43 & 2.86 & 2.83 & 63.18 & 60.02 & \begin{tabular}{|l|}
21.41 \\
\end{tabular} & 20.33 & 33.88 & $\mathbf{3 3 . 8 7}$ \\
\hline & $\mathbf{R}$ & 62.33 & 63.33 & 4.20 & 4.13 & 0.70 & 0.70 & 0.81 & 0.79 & 16.27 & 16.47 & 2.55 & 2.50 & 50.48 & 50.04 & 15.5 & 15.10 & 30.70 & 30.18 \\
\hline L.S.D at $5 \%$ & & N.S & N.S & N.S & N.S & N.S & N.S & N.S & N.S & 0.57 & 0.87 & 1.31 & 2.07 & 1.93 & N.S & N.S & N.S & 1.11 & 1.24 \\
\hline
\end{tabular}

K = K173 cv. R = Royston Petrie 
Table (4): Effect of the sowing dates and cultivars on N\%, P\%, K\% and protein \% and total sugars \% on green seeds of soybean plants during the two seasons of 2017 and 2018 .

\begin{tabular}{|c|c|c|c|c|c|c|c|c|c|c|c|}
\hline \multicolumn{2}{|l|}{ Treatments } & \multicolumn{2}{|l|}{$\mathrm{N} \%$} & \multicolumn{2}{|l|}{ Protein \% } & \multicolumn{2}{|l|}{ P\% } & \multicolumn{2}{|l|}{ K \% } & \multicolumn{2}{|c|}{ Total sugars \% } \\
\hline & & $\begin{array}{r}1^{\text {st }} \\
\text { season }\end{array}$ & $\begin{array}{r}2^{\text {nd }} \\
\text { season }\end{array}$ & $\begin{array}{c}1^{\text {st }} \\
\text { season }\end{array}$ & $\begin{array}{r}2^{\text {nd }} \\
\text { season }\end{array}$ & $\begin{array}{r}1^{\text {st }} \\
\text { season }\end{array}$ & $\begin{array}{r}2^{\text {nd }} \\
\text { season }\end{array}$ & $\begin{array}{r}1^{\text {st }} \\
\text { season }\end{array}$ & $\begin{array}{r}2^{\text {nd }} \\
\text { season }\end{array}$ & $\begin{array}{r}1^{\text {st }} \\
\text { season }\end{array}$ & $\begin{array}{r}2^{\text {nd }} \\
\text { season }\end{array}$ \\
\hline \multicolumn{12}{|c|}{ Sowing date } \\
\hline \multicolumn{2}{|l|}{ First April } & 6.92 & 6.95 & 43.23 & 43.63 & 1.70 & 1.78 & 5.61 & 5.63 & 4.62 & 4.73 \\
\hline \multicolumn{2}{|l|}{ First May } & 6.87 & 6.93 & 42.92 & 43.34 & 1.85 & 1.93 & 5.73 & 5.62 & 4.87 & 4.88 \\
\hline \multicolumn{2}{|l|}{ First June } & 6.77 & 6.73 & 42.30 & 42.30 & 1.74 & 1.72 & 5.51 & 5.51 & 4.45 & 4.50 \\
\hline \multicolumn{2}{|l|}{ L.S.D at $5 \%$} & N.S & N.S & N.S & N.S & N.S & N.S & N.S & N.S & 0.13 & 0.11 \\
\hline \multicolumn{12}{|c|}{ Cultivars } \\
\hline \multicolumn{2}{|l|}{$\mathbf{K}$} & 6.78 & 6.81 & 42.38 & 42.56 & 1.80 & 1.84 & 5.97 & 5.93 & 4.91 & 4.96 \\
\hline \multicolumn{2}{|l|}{$\mathbf{R}$} & 6.99 & 6.98 & 43.69 & 43.63 & 1.72 & 1.78 & 5.26 & 5.24 & 4.41 & 4.56 \\
\hline \multicolumn{2}{|l|}{ L.S.D at $5 \%$} & 0.1 & 0.09 & 0.67 & 0.87 & N.S & 0.07 & 0.13 & 0.14 & 0.03 & 0.04 \\
\hline \multicolumn{12}{|c|}{ Interaction } \\
\hline \multirow[t]{2}{*}{ First April } & $\mathbf{K}$ & 6.79 & 6.85 & 42.44 & 42.81 & 1.94 & 1.97 & 5.94 & 6.01 & 4.63 & 4.87 \\
\hline & $\mathbf{R}$ & 6.97 & 7.00 & 43.56 & 43.75 & 1.46 & 1.59 & 5.28 & 5.26 & 4.40 & 4.50 \\
\hline \multirow[t]{2}{*}{ First May } & $\mathbf{K}$ & 6.80 & 6.70 & 42.50 & 41.88 & 1.78 & 1.84 & 6.20 & 6.03 & 4.67 & 4.60 \\
\hline & $\mathbf{R}$ & 6.93 & 7.00 & 43.31 & 43.75 & 1.93 & 2.01 & 5.26 & 5.21 & 4.47 & 4.57 \\
\hline \multirow[t]{2}{*}{ First June } & $\mathbf{K}$ & 6.63 & 6.73 & 41.44 & 42.06 & 1.69 & 1.7 & 5.77 & 5.76 & 4.53 & 4.80 \\
\hline & $\mathbf{R}$ & 6.90 & 6.83 & 43.13 & 42.69 & 1.78 & 1.74 & 5.25 & 5.25 & 4.37 & 4.60 \\
\hline \multicolumn{2}{|l|}{ L.S.D at $5 \%$} & N.S & N.S & N.S & N.S & N.S & N.S & N.S & N.S & N.S & N.S \\
\hline
\end{tabular}


Concerning the interaction between sowing dates and the cultivars presented in Table (2). The results elucidated that there were not significant differences among the interaction treatments in the first and the second seasons.

\section{Chemical composition}

Data in Table (4) indicated that the vegetable soybean plants grown in the second sowing date $1^{\text {st }}$ May) gave significantly increased the total sugars content in green seeds in the both seasons. These results are in harmony with (Veronika Kim 2019) Biochemical analysis of vegetable soybeans showed that with the delay of sowing in later terms the content of the main components of the chemical composition slightly increases.

It is obvious from the data in Table (4) that the K173 cultivar had significant differences in $\%$ phosphorus and\% Potassium contents in green seeds in both seasons except phosphorous content, it is not significant in the first season, it was not moral . Also the K173 cultivar gave the highest value of total sugars contents in green seeds in the both seasons this might be due to the protein and total sugars are negatively associated (Hymowitz et al. 1972), too much protein leads to a lack of sweetness, an important component of flavor. These results are generally in agreement with those reported by (Saldivar $\boldsymbol{e t}$ al. 2011) all edamame seed attributes measured. Significant differed among the varieties for changes in chemical soybean seed composition.

Results of Table (4) revealed that the statistical analysis of the data indicated that the interaction between sowing date and the vegetable soybean cultivars were not significant in the first and the second seasons.

\section{CONCLUSION}

The results from this study indicated that vegetable soybean could be successfully grown in Egypt. Growth and yield for the first of April and first of May planting dates were better than the first of June planting. Sowing date had a significant impact on marketable yield.

\section{REFERENCES}

Arathoon, A.J. (2015). Agronomic studies on edamame (vegetable soybean) in Kwazulu-Natal. University of KwaWulu-Natal. PhD Dissertation.

Basavaraja, G.T. ; G.K. Naidu and P.M. Salimath (2005). Evaluation of Vegetable Soybean Genotypes for Yield and Component Traits. Karnataka Journal of Agricultural Sciences, 18(1):27-31.

Bastidas, A.M. ; T.D. Setiyono ; A. Dobermann ; K.G. Cassman ; R.W. Elmore ; G.L. Graef and J.E. Specht(2008). Soybean 
Sowing Date: The Vegetative, Reproductive, and Agronomic Impacts Article Crop Science. March, 10.2135.

Board, J.E. ; M. Kamal and B.G. Harville (1992). Temporal importance of greater light interception to increase narrow-row soybean. Agro. J., 84: 575- 579.

Board J.E. ; M.S. Kang and B.G. Harville (1999). Path analysis of the yield formation process for late-planted soybean. Agro. J., 91: 128-135.

Boquet, D.J. (1990). Plant population density and row spacing effects on soybean at post-optimal planting dates. Agro. J., 82: 59-64.

Brown, J.D. and O. Lilleland (1946). Rapid determination of potassium and phlame- Photometry. Proc. Amer. Soc.Hort.Sci., 48: 341-346.

Chadha, M.L. and M.O. Oluoch (2004). Vegetable soybean research and development in Africa. In VII World Soybean Research ConferenceIV International Soybean Processing and Utilization Conference-III Congresso Brasileiro de Soja. Brazil, pp. 921-928.

Dubois, M. ; A. Gilles ; K.J. Hamilton ; P.R. Rebers and P.A. Smith (1975). Actorimetric methods sobstances. Anal Chem., 28: 350

Hoeft, R.G. ; E.D. Nafziger ; R.R. Johnson and S.R. Aldrich (2000). Modern corn and soybean production. MCSP Publications, Champaign.

Hymowitz, T. ; F.I. Collins ; J. Panczner and W.M. Walker (1972). Relationship between the content of oil, protein, and sugar in the soybean. Agronomy Journal, 64(5):613-616

Jackson, M.L. (1967). Soil chemical analysis. Prentice-Hall of India pp.144- 197.

Konovsky, J. ; T.A. Lumpkin and D. Mcclary (1994). Edamame the

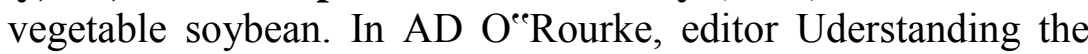
Japanese food and agrimarket: a multifaceted opportunity. Binghamton, pp. 173-181.

Konovsky, J. ; T.A. Lumpkin and D. Mcclary (2015). Edamame the vegetable soybean. http://www.coolbean.info/pdf/soybean_research/ library/ and_food_production. Food Sci. Technol., 49: 89-95.

Kristensen, M.D. ; N.T. Bendsen ; Sh. M. Christensen ; A. Astrup and A. Raben (2016). Meals based on vegetable protein sources (beans and peas) are more satiating than meals based on animal protein sources - a randomized cross-over meal test study. Food \& Nutrition Research №60: 32634. 
Kumar, V. ; A. Rani ; L. Goyal ; D. Pratap ; S.D. Billore and G.S. Chauhan (2011). National Research Centre for Soybean, Khandwa Road, Indore, M.P., India.

Lee, J.D. and Y.H. Hwang (1998). Quality evaluation for vegetable use in local soybean cultivars with various seed coat color. Korean J. Crop Sci., 43: 83-88.African Journal of Agricultural Research, 5(18): 2556-2562.

Naeve, S.L. ; B.D. Potter ; S.R. Quiring ; T.A. O'Neil and J.E. Kurle (2004). Influence of soybean plant population and row spacing on development and yield across planting dates in Minnesota. Available at 11Dec.2007). Univ. of Minnesota, Minneapolis.

Nishioka, H. and T.Okumura (2008). Influence of sowing time and nitrogen topdressing at the flowering stage on the yield and pod character of green soybean (Glycine max (L.) Merril). Plant Prod. Sci., 11(4): 507- 513.

Pregl, F. (1945). Quantitative organic micro-analysis 4th Ed., J. and Churchill, Ltd, London.

Ramya, V. and U.V. Mummigatti (2015). Characterization of vegetable soybean genotypes for phenological, physiological and yield attributing traits. Karnataka Journal of Agricultural Sciences, 28:500- 503.

Saldivar, X. ; Y.J. Wang ; P. Chen and A. Hou (2011). Changes in chemical composition during soybean seed development. Food Chemistry, 124:1369-1375.

Shanmuga, S. (2009). Vegetable Soybean Research Needs for Production and Quality Improvement. AVRDC, Tainan, Taiwan. pp. 30-42..

Slaton, N.A. ; B.R. Golden ; R.E. De Long and C.G. Massey (2008). Green bean yield as affected by nitrogen fertilization strategy. In W.E.Sabbe, ARKANSAS SFERTILITY STUDIES. AAES Research Series., pp.77-79.

Snedecor, G. W. and W. G. Cochran (1980). Statistical Methods. 7th ed. Iowa State Univ. Press, Ames. Iowa, U.S

Sych, S. (2010). Non-traditional vegetable legume crops. Vegetable growing. №8. pp. 50-53.

Tsindi, A. ; R. Kawuki and P. Tukamuhabwa (2019). Adaptation and Stability of Vegetable Soybean Genotypes. African Crop Science Journal, 27:267-280. 
Veronika Kim (2019). Influence of sowing term on high yield of vegetable soybeans in Uzbekistan. Epra. International Journal of Research and Development (IJRD).

Yadava, U.L. (1986). A rapid and nondestrutive method to determine chlorophyll in intact leaves. HortScience, Alexandria, 21: 1449-1450

Zhang, Q.Y. ; S.J. Herbert and X.W. Pan (2007). Current status, production problem and prospects of vegetable soybean in China. Soybean Sci., 26(6): 950-954.

Zhang, Q.Y. ; S.J. Herbert and X.W. Pan (2008). Field performance of vegetable soybean varieties (lines) in Northeast USA . Soybean Sci., 27(3): 409-413.

Zhang, Q. ; J. Gao ; S.J. Herbert ; Y. Li and A. M. Hashemi (2010). Influence of sowing date on phenological stages, seed growth and marketable yield of four vegetable soybean cultivars in North-eastern USA. African Journal of Agricultural Research, 5(18): 2556-2562.

$$
\begin{aligned}
& \text { دراسة عن افضل ميعاد لزراعة وإنتاج فول الصويا } \\
& \text { الخضر تحت الظروف المصرية. } \\
& \text { نبيلة عبد الباسط عويس } \\
& \text { |قسام بحوث الخضر - معهد بحوث البساتين - مركز البحوث الزراعية - الجيزة - مصر . }
\end{aligned}
$$

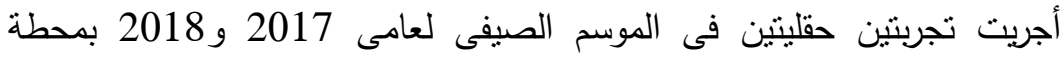

$$
\begin{aligned}
& \text { بحوث البساتين بالقناطر الخيرية التابعة لمعهد بحوث البساتين- مركز البحوث الزراعية }
\end{aligned}
$$

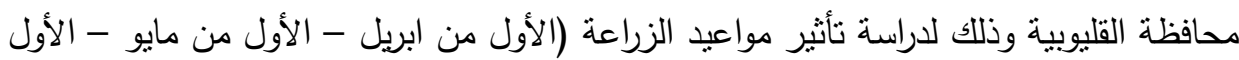

$$
\begin{aligned}
& \text { من يونيه ) على صنفين من أصناف الفول الصويا الخضر (كى 173- روى-ستون) تحت التصن }
\end{aligned}
$$

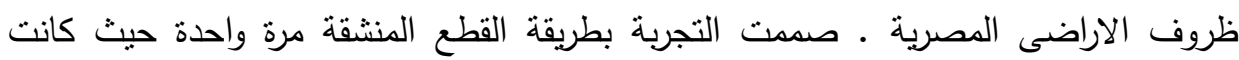

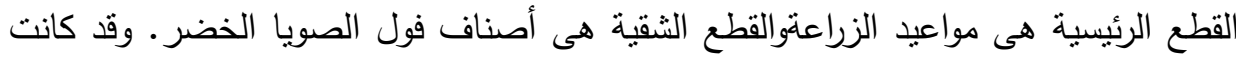

$$
\begin{aligned}
& \text { النتائج كما يأنى : الرئية }
\end{aligned}
$$

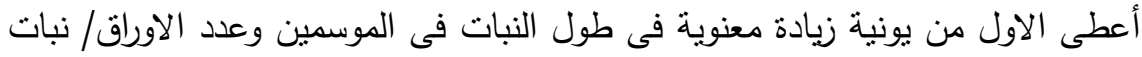

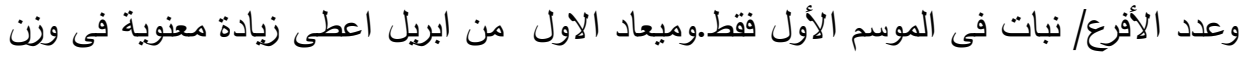

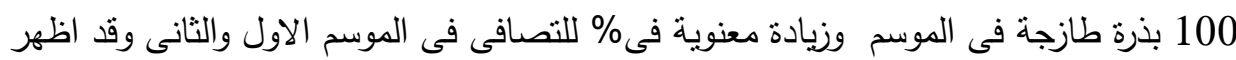

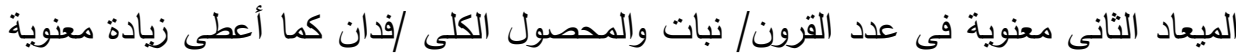

$$
\begin{aligned}
& \text { فى محتوى البذور من السكريات الكلية فى الموسمين. }
\end{aligned}
$$




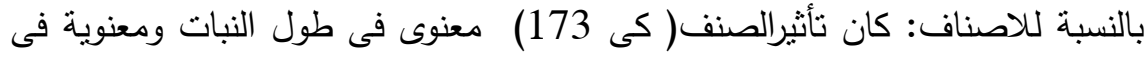

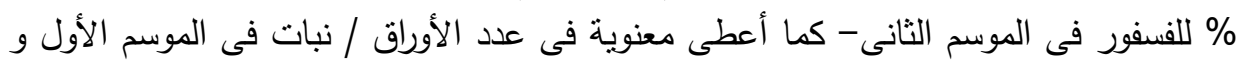

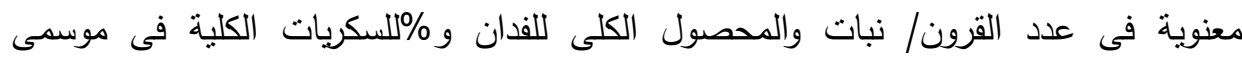

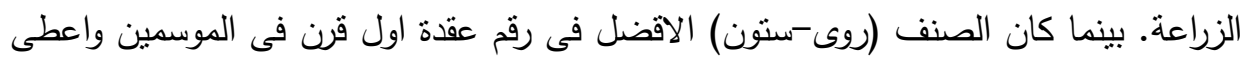

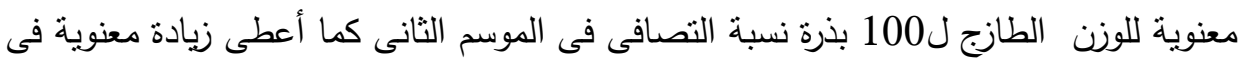

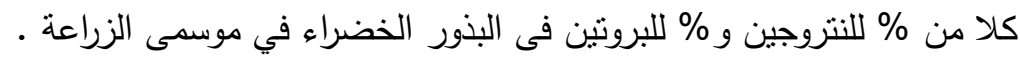

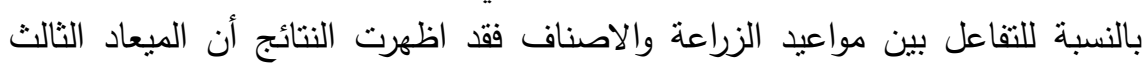

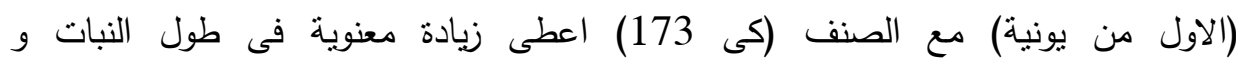

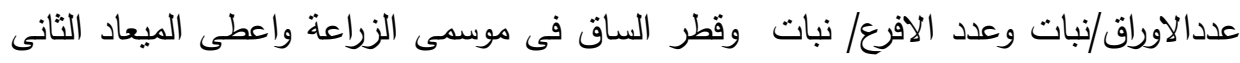

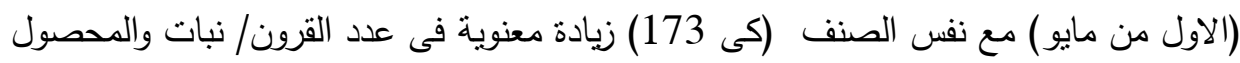

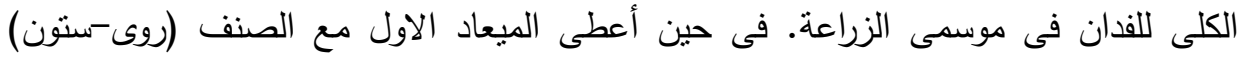

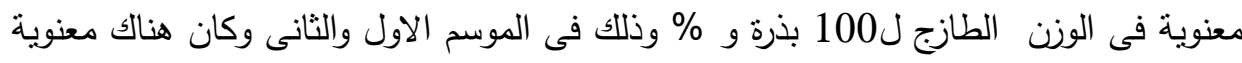

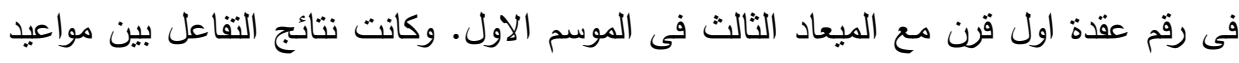

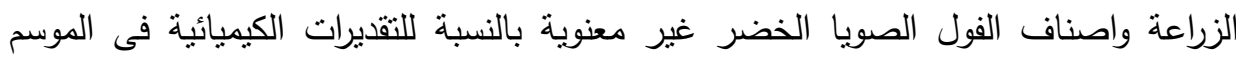

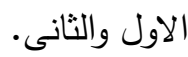

